осмысление // Революции и реформы в странах Центральной и Юго-Восточной Европы: 20 лет спустя. Российская политическая энциклопедия (РОССПЭН), 2011. - C. 145-151.

3. Яжборовская И.С. Глобализация и опыт трансформации в странах Центральной и Юго-Восточной Европы. - М.: «Academia», 2008. - 378 с.

4. Барабанов М.В. Приближая «постсоциалистическую» трансформацию в странах Восточной Европы: о некоторых «исторических предпосылках» // Локус: люди, общество, культура, смыслы. 2015. Т. 4. С. 41-49.

Статья отправлена: 09.04.2017 г.

() Мокшин В.К., Шипелик О.В.

\title{
ЦИТ: иа117-051
}

DOI: 10.21893/2415-7538.2016-05-1-051

УДК 341.74(477)+(450)

Бобрикова О.-I.C. ДИПЛОМАТИЧНІ ВІДНОСИНИ УКРАЇНИ 3 ІТАЛІЙСЬКОЮ РЕСПУБЛІКОЮ

Наиіональний університет біоресурсів і природокористування Украйни, вул. Героїв Оборони, 15, Київ, 03041

Bobrykova O.-I.S.

\section{DIPLOMATIC RELATIONS BETWEEN UKRAINE AND THE ITALIAN} REPUBLIC

National university of life and environmental sciences Ukraine Geroev Oboronyi st., 15, Kyiv, 03041

Анотація. У статті розглянуто дипломатичні відносини Украйни та Італійської республіки, досліджено історію та шляхи розвитку міжнародних відносин між країнами в умовах сучасної політичної ситуачії у світі та роль Італії в інтеграиійних процесах вступу Украӥни до ЄC.

Ключові слова: украӥнсько-італійські відносини, Італійська республіка, дипломатичні відносини, українсько-італійське співробітництво.

Abstract. In the article the diplomatic relations between Ukraine and the Italian Republic, examines the history and the development of international relations between countries in the current political situation in the world and the role of Italy in the integration process of Ukraine's accession to the EU.

Keywords: Ukrainian-Italian relations, the Italian Republic, diplomatic relations, Ukrainian-Italian cooperation.

Мета даної роботи - розглянути дипломатичні відносини між Україною та Італійською республікою, дослідити динаміку та основні напрямки розвитку політичних, економічних, науково-технічних та культурних відносин між країнами, роль Італійської республіки на шляху України до євроінтеграції.

Розвиток дипломатичних відносин та їх політичне значення являється актуальним та важливим аспектом для подальшої позитивної співпраці між Україною та Італією, враховуючи напрям зовнішньополітичного курсу України в бік повноправного членства в СС. 
Двосторонні відносини між країнами розпочалися після проголошення незалежності України. Італія однією 3 перших країн визнала незалежність України 28 грудня 1991 р. За період незалежності України було підписано багато угод та договорів між країнами, важливих як для Італії, так і для України. Дуже відчутною для підвищення геополітичного статусу України $\epsilon$ неодноразова iі підтримка італійським урядом на шляху інтеграції до Євросоюзу.

Українсько-італійські відносини привернули увагу багатьох науковцівполітологів. Серед авторів слід відзначити таких як Перепелиця Є.А. («Українсько-італійське міждержавне співробітництво в контексті європейської інтеграції») та Гамоцький В.С. («Українські інтереси у співробітництві 3 Італією до ювілею українсько-італійських відносин») $[1,2]$, які проаналізували сучасний стан відносин між Україною та Італією як країни-члена Європейського Союзу.

Дипломатичні відносини між Україною та Італійською республікою (далі IP) офіційно підтверджено 29 січня 1992 року у Протоколі про встановлення дипломатичних відносин між Україною і Італійською Республікою [6]. 3 часу встановлення дипломатичних відносин відбулося чотири офіційні візити Президента України до Італії, два візити президента та два візити прем'єрміністра Італії до України [3]. Дипломатичні представництва України в Італійській Республіці відкриті у Римі, Неаполі, Мілані [7].

На сьогоднішній день договірно-правова база налічує 31 документ, що регулює міжнародно-правові відносини між Україною та Італійською республікою в тому числі в економіці, екології, в галузі ядерної безпеки та радіаційного захисту. В різні роки було підписано низку дуже важливих документів, що визначають дипломатичні відносини між Україною та IP: Протокол про встановлення дипломатичних відносин між Україною та IP (29.01.92); Договір про дружбу і співробітництво між Україною та IP (03.05.95); Конвенція між Урядом України i Урядом IP про уникнення подвійного оподаткування доходів і капіталу та попередження податкових ухилень (26.02.97); Консульська конвенція між Україною та IP (23.12.2003)[5].

Від моменту проголошення незалежності Україна почала процес створення своєї власної зовнішньої політики як суверенна держава. Одним з основних завдань являлося і являється на сучасному етапі розвитку країни створення правової бази для найбільш раціональних та прийнятних умов для реалізації національних інтересів та забезпечення національної безпеки України. I однією 3 найбільш значущих країн для подальшого політичного розвитку України $\epsilon$ Італія, уряд якої повсякчас виявляє підтримку Україні на іiї шляху до євроінтеграції.

Однією з найважливіших подій для України була безпрецедентна зустріч, що відбулася 21 травня 1996 р. у Римі, де міністр закордонних справ України Г.Удовенко зустрівся з «трійкою міністрів» закордонних справ країн СС: Італії (яка головувала на той час в СС), Іспанії та Ірландії. Уперше в історії європейської дипломатії «трійка міністрів» виступила зі спеціальною заявою ЄС щодо України щодо забезпечення незалежності та територіальної цілісності 
України як важливої складової безпеки в Свропі. А з 31 травня по 1 червня 1996 р. у Відні відбулося чергове засідання міністрів закордонних справ держав-учасниць Центральноєвропейської ініціативи (далі ЦЄІ), в ході якого Україна втупила до її складу.

Італія завжди була значно зацікавлена у економічному співробітництві 3 Україною, але це партнерство рухалося низькими темпами, головним чином через брак економічних реформ в Україні, необхідних для розвитку повноцінних економічних відносин з європейськими країнами. Утім експорт 3 України до Італійської Республіки чорних металів посідає провідне місце в структурі українського експорту.

Україна й Італійська республіка планують розширити торгово-економічні відносини, зокрема в сільському господарстві (зернове та олійне виробництво), що обговорювалося 6 жовтня 2014 р. під час зустрічі Міністра аграрної політики України із заступником Міністра продовольства i сільського господарства Італії [3].

27-31 січня 2017 р. в містах Рим, Піза, Торіно працювала місія українських урядовців та експертів 3 енергетичних питань. Українські фахівці вивчили досвід італійських державних установ, агенцій та компаній у використанні італійських технологій у сфері виробництва електроенергії з альтернативних джерел (енергії сонця, вітру, біомаси) та можливості застосування схожих технологій в Україні. Використовуючи набутий місією досвід з'являється можливість реалізації спільних українсько-італійських проектів із залученням європейського фінансування та подальший розвиток національної енергетичної системи шляхом впровадження сучасних технологій [8].

Науково-технічне співробітництво між країнами полягає в реалізації двосторонніх угод $\mathrm{i}$ договорів та наукового обміну між дослідними та університетськими закладами, що постійно розширюють свою географію.

Культурно-гуманітарні відносини між Україною та Італією регулюються Угодою про співробітництво в галузі освіти, культури і науки між Кабінетом Міністрів України та Урядом Італійської Республіки від 11.11.1997 р., що набула чинності 11.04.2000 p.

Українсько-італійське партнерство в цих галузях активно розвивається.

На сьогодні укладено близько 50 угод про співробітництво між українськими та італійськими вищими навчальними закладами та науководослідними центрами.

Українська громада на 1 січня 2016 року склала 240141 осіб, тобто українці - найчисельніша етнічна група в Італії. Для популяризації української культурної, історичної та мистецької спадщини в Італії проводяться різноманітні заходи спрямовані на зближення двох націй. В світлі останніх подій 19 лютого 2017 року на центральній площі Риму українці та італійці вшанували пам'ять Небесної сотні.

Складною проблемою у розвитку культурно-гуманітарного співробітництва між країнами являється процес трудової міграції. Це питання активно обговорюється та плануються шляхи його вирішення на державному рівні. 
Італійська республіка неодноразово підтримувала і підтримує Україну. Це, наприклад, реструктуризація українського боргу, фінансова допомога «Великої сімки», підтримка в СС та МВФ. Дуже важливим аспектом для України як партнера Італійської республіки являється прийняття останньою учасників подій на Майдані та постраждалих на Сході України на лікування та реабілітацію, а також організація гуманітарної допомоги та консолідація волонтерського руху в Італії.

31 січня 2017 р. розпочалася програма допомоги Україні на суму 35,75 млн. дол. США, в ході якої передбачено забезпечення продовольчими товарами та ваучерами громадян України, що постраждали внаслідок військових дій та потерпають від нестачі харчування.

Зі свого боку Україна підтримує Італійську республіку на політичному та культурному рівні. В якості партнера та дружньої країни Україною передано Італії у грудні 2016 р. 17 всесвітньовідомих картин, які були викрадені злочинцями із музею Верони та затримані українською прикордонною службою при спробі переправи до Молдови.

Протягом останнього року дипломатичні відносини між Україною та Італійською республікою почали набувати підвищеної активності та позитивної динаміки на всіх рівнях. Італія починає відкривати для себе Україну як повноцінного партнера. Італія підтримує курс проєвропейських реформ та адаптацію українського законодавства до європейських норм, сприяє співпраці України з СС, бере активну участь в реалізації санкцій СС щодо Росії. Для України важливою $є$ підтримка Італії в міжнародних організаціях, зокрема в СС, НАТО та в рамках «Великої сімки».

Отже, можна охарактеризувати якість та динаміку розвитку дипломатичних відносин між Україною та Італійською республікою, як досить нестабільні, що роками не розвивалися, або на деякий час ставали найбільш активними та корисними у порівнянні з іншими країнами Свросоюзу. Особливо прогресують стосунки між країнами упродовж останніх років. Підтримка України Італією у прагненні України до вступу до Євросоюзу має вагоме значення і для розвитку стабільних стосунків України з іншими європейськими країнами. Таким чином, можна стверджувати, що високий рівень довіри між сторонами, інтенсивний ріст дипломатичних відносин, плідна співпраця в різних галузях науки та мистецтва - запорука повноцінних двохсторонніх дипломатичних відносин між Україною та Італійською республікою, що можуть призвести до подальших максимально взаємовигідних умов співіснування двох суверенних європейських країн.

\section{Список використаної літератури}

1. Перепелиця Свген Анатолійович. Українсько-італійське міждержавне співробітництво в контексті європейської інтеграції (1991-2006рр.): дис... канд. іст. наук: 07.00.02 / НАН України; Інститут історії України. — К., 2007. — 225 арк. - Бібліогр.: арк. 190-225.

2. Гамоцький В. С. Українські інтереси у співробітництві з Італією (до ювілею українсько-італійських відносин) / В.С.Гамоцький //Науковий вісник 
Дипломатичної академії України. - К., 2002. - Вип. 7: Зовнішня політика та дипломатія: теорія, історія, практика. - С. $262-266$.

3. Політичні відносини між Україною та Італією [Електронний ресурс]. Режим доступу: http://italy.mfa.gov.ua/ua/ukraine-it/diplomacy

4. Двосторонні Українсько-Італійські відносини [Електронний ресурс]. Режим доступу: http://www.ambucraina.com/Relazioni ucraino italiane/Ucraino/Dvostoronka.htm

5. Договірно-правова база між Україною та Італією [Електронний ресурс]. Режим доступу: http://italy.mfa.gov.ua/ua/ukraine-it/legal-acts

6. Протокол про встановлення дипломатичних відносин між Україною та Італійською Республікою [Електронний ресурс]. Режим доступу: http://zakon2.rada.gov.ua/laws/show/380 024

7. Посольства України в Італії [Електронний ресурс]. Режим доступу: http://mfa.gov.ua/ua/about-mfa/abroad/embassies/54

8. Співпраця у сфері енергетики [Електронний ресурс]. Режим доступу: http://italy.mfa.gov.ua/ua/ukraine-it/trade/Collaborazione+in+sfera+energetica

9. Україна передала Італії 17 картин італійських художників, врятованих українськими правоохоронцями та прикордонниками [Електронний ресурс]. Режим доступу: http://www.president.gov.ua/search?query=\%D1\%96\%D1\%82\%D0\%B0\%D0\%BB\% D1\%96\%D1\%8F\&

Науковий керівник: к.і.н., доцент Сєкунова Ю.В. Стаття надіслана: $30.03 .17 \mathrm{p}$.

(C) Бобрикова O.-I.C.

ЦИТ: иа117-063

DOI: 10.21893/2415-7538.2016-05-1-063

УДК 338.43

\section{ВИБОРИ І ВИБОРЧА СИСТЕМА США І УКРАЇНИ ELECTIONS AND THE ELECTORAL SYSTEM THE USA AND UKRAINE к.i.н., доц. Сєкунова Ю.В. / c.h.s., as.prof. Syekunova Yu.V. студент Кветницька П.I. / student Kvetnicka P.I.} Київський наиіональний університет біоресурсів та природокористування Украйни, Київ, Героїв Оборони 11, 03041 Kiev National University of Life and Environmental Sciences, Kyiv, Geroiv Oborony 11, 03041

Анотація. В даній статті описано виборчі системи й організацію виборів у США та в Украйні. А саме історію виборів та їх особливості, виборчі прочеси, організацію виборів та ключові відмінності в виборчих системах.

Ключові слова: політика, вибори, держава, виборчі системи.

Annotation. This article describes the electoral system and the organization of elections in the US and Ukraine. That is the history of elections and their features, electoral processes, organization of elections and the key differences in electoral systems.

Keywords: politics, elections, government, election system. 